Article

\title{
Exploring the Impact of Responsible Leadership on Organizational Citizenship Behavior for the Environment: A Leadership Identity Perspective
}

\author{
Hongdan Zhao * and Qiongyao Zhou * \\ School of Management, Shanghai University, Shanghai 200444, China \\ * Correspondence: jimmyzhaoxin@i.shu.edu.cn (H.Z.), zhouqiongyao@shu.edu.cn (Q.Z.)
}

Received: 13 January 2019; Accepted: 11 February 2019; Published: 13 February 2019

\begin{abstract}
Drawing on social identity theory, the authors demonstrated how and when responsible leadership might relate to employee's organizational citizenship behavior for the environment (OCBE). Using data collected from 302 subordinates from one service chain hotel in China across 2 phases, this study discussed the influence mechanism of responsible leadership on OCBE, as well as the roles of leader identification and the perceived role of ethics and social responsibility (PRESOR). Empirical results revealed that responsible leadership was positively related to OCBE, and that leader identification played a mediating role between responsible leadership and OCBE. The relationship between leader identification and OCBE was positively moderated by PRESOR, which also moderated the indirect effect of responsible leadership on OCBE through leader identification, such that this relationship was stronger when PRESOR was high. Finally, we outlined the theoretical and practical implications and proposed some promising aspects and value variables for future research.
\end{abstract}

Keywords: responsible leadership; leader identification; organizational citizenship behavior for the environment; the perceived role of ethics and social responsibility

\section{Introduction}

In recent years, the ideas that "involving everyone in environmental protection" and "clear waters and green mountains are as good as mountains of gold and silver" highlight the country's awareness of ecological protection. In response, nearly every industry has been required to implement corporate ecological performance systems and practices. However, most studies still concentrate on environmental management practices from the consumer perspective, and remain lacking in systematic investigations [1]; especially, the role of the employee perspective within organizations was neglected to some extent [2,3]. However, the truth is that employee active green participation (e.g., reducing waste and conserving energy) is vital for organizations' sustainable development [4]. Therefore, scholars have started to focus on the concept of organizational citizenship behavior for the environment (OCBE) in response to the function of employees to their organization's sustainable development $[5,6]$. OCBE refers to environmental efforts that are individual, voluntary and discretionary acts within the organization setting, but which are not explicitly rewarded or required by the formal management system [7]. As a type of proactive and voluntary work behavior, employee OCBE not only aims to improve the status quo, but also has been considered as a critical driver of desirable outcomes such as corporate sustainability performance, corporate social responsibility or organizational effectiveness $[7,8]$. Therefore, from responding to the major policies of the state and its utility, individual's OCBE is of real importance.

Not surprisingly, because of the sustainable importance and potential benefits of OCBE, more and more scholars have promoted it in organizations [9]. In past research, it was demonstrated that several 
factors influence employee OCBE, including perceived supervisory support for environmental efforts, human resource management practices and leadership styles $[5,9,10]$. As leaders are adept at leading and motivating subordinates and play irreplaceable roles in supporting and shaping employees' willingness to perform extra-role behaviors [11,12], leadership has been recognized as an essential factor in determining employee OCBE. In particular, responsible leadership, which requires leaders to be morally conscious toward the stakeholders inside and outside of the corporation, has been theorized and interpreted as an effective antecedent of employee OCBE. Because employees are critical internal stakeholders, responsible leadership can raise employees' levels of green participation motivation and encourage the commitment to achieving sustainable goals $[13,14]$.

As applied here, responsible leadership examines the leadership dynamics within the context of stakeholder society, and includes the ethical perspective, i.e., the norms, values, and principles [15] which are different from traditional leadership research focusing on cognition and behavior [16]. Nevertheless, responsible leadership is also committed to mobilizing different stakeholders to cooperate and work together for a common sustainable development vision. Responsible leaders care for their followers, and set an example of how to do things the right way concerning making decisions. So, how responsible leadership influences an employee's OCBE is a fundamental, and is a practical research topic that needs to be investigated. However, there is a lack of empirical studies that focus on this relationship; in particular, the mechanism through which responsible leadership relates to OCBE has been less discussed, and there is still a shortage of in-depth research on this relationship. Therefore, our first purpose in this research was to consider the standard problems and fill this gap, which can help to extend the research on leadership and OCBE by examining whether responsible leadership inhibits employee OCBE.

Some existing leadership studies have focused on the theory about how leaders cultivate employees' extra-role behavior by fostering and influencing their self-concepts [17,18]. The reviews are attractive in advancing leadership research because they turn our attention from leaders' effects on social and organizational outcomes to employees' motivation [19]. Unfortunately, most of the previous research about self-concepts focused on individual identity [20] or organizational identity [21], without considering leader identification. We suggest that leader identification reflects the level of overlap between individual identity and the leader's identity [22]. When employees have a high level of identification with the leader, the effectiveness of the leader's beliefs, goals and values incorporate themselves into employees' self-concept, i.e., they are likely to internalize and depend on the leader's expectations to understand their own work role. Responsible leadership is also devoted to articulating a promising vision and setting a model which will encourage followers to generate a strong intention to develop and maintain a mental connection with the identified responsible leader. According to social identity theory, when employees have personal leader identification, they are more likely to act on the leader's behalf, because they share similar interests and norms with their leaders and treat the leader's perspectives and beliefs as their own. They are willing to respond to sustainable principles and follow the leader's example by performing OCBE to support such initiatives. Therefore, in our study, we suppose that the reason why responsible leadership influences OCBE is that responsible leadership improves employees' abilities to identify with leaders. In turn, leader identification enhances employee OCBE.

Moreover, we examine the influence of the perceived role of ethics and social responsibility (PRESOR) on the relationship of leader identification and OCBE, and the indirect association of responsible leadership on OCBE via leader identification, which refers to the importance of perceived ethics and social responsibility as they apply to decision-making processes [23]. SJ Vitell and JG Paolillo [24] mentioned that PRESOR was likely to be a crucial background factor and a key determinant of whether or not an ethical issue was perceived in a given situation. In turn, PRESOR should have a positive effect on organizational success and employee decisions, because the ethical judgments of employees are likely to influence their behavior [25]. We consider that for an employee who already has a high level of cognition of ethics and social responsibility, the effect of responsible 
leadership and leader identification may become stronger, since the individual's values emphasize the importance of ethics and social responsibility for sustainable development and are consistent with the concept of responsible leadership. Consistency in attitudes toward responsible leadership increases the employee's awareness of sustainable corporate values and their support and identification toward their leaders, thus increasing their OCBE. That is, an employee's motivation to engage in OCBE may be nourished by the influence of leader identification and PRESOR, and it is also expected to moderate the indirect relationship between responsible leadership, leader identification and OCBE (see Figure 1).

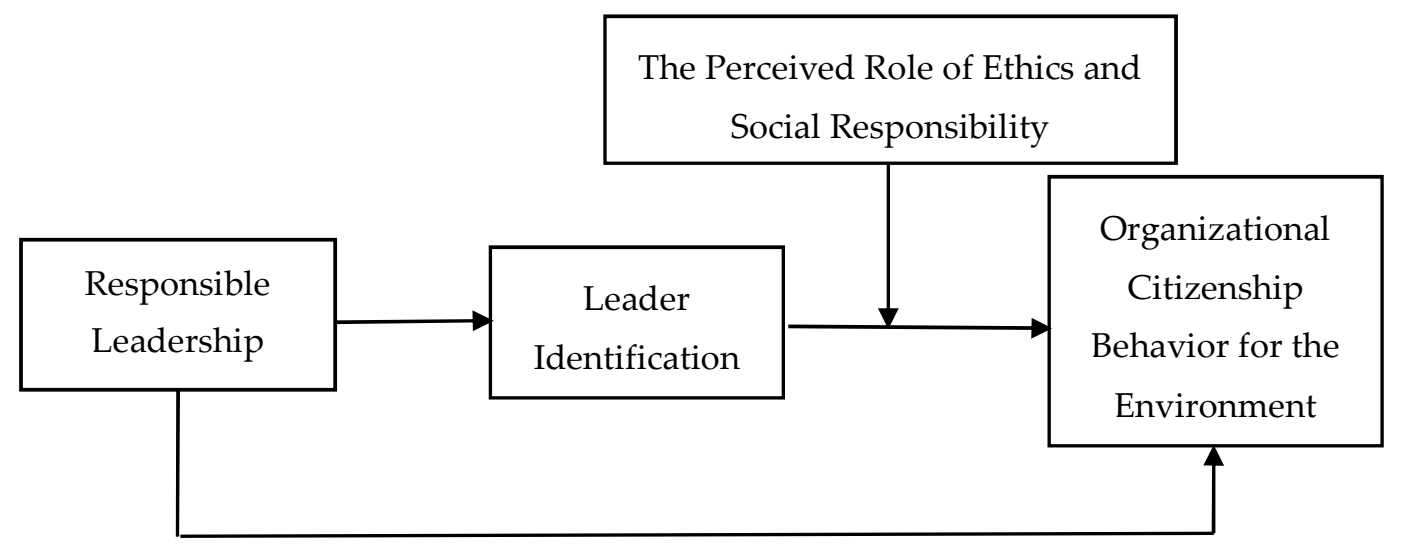

Figure 1. The research model of this study.

Our investigation makes some contributions to this research by exploring the relationship between responsible leadership and OCBE. First, we identify antecedents of OCBE. Our study suggests that responsible leadership can be a means to foster and strengthen employee OCBE, which has rarely been investigated. Second, we extend OCBE research by concentrating on a different mechanism; especially from the self-concept perspective, we suggest that leader identification renders inconsistent the findings on how personal identification could shape employee behavior at work. Third, the moderating effect of PRESOR reinforces an individual's value perspectives by influencing the employee's sense of OCBE and sustainable organizational development broadly.

\section{Theory and Hypotheses}

\subsection{Responsible Leadership and $O C B E$}

Responsible leadership focuses consciously on matters of responsibility, such as appropriate moral decision-making, trust building, sustainable development and green action choices [26]. According to T Maak and NM Pless [14], responsible leadership is seen as a leadership style where a leader acts as a weaver of stakeholder relationships and responds to both existing gaps in theory and practical leadership challenges. Therefore it has received much attention in recent decades, and has become an essential and particular studied leadership style. Actually, there is much research examining the effectiveness of responsible leadership as it relates to employee behaviors. K Groves [27] proposed that employee ideas regarding CSR, and their willingness to devote themselves to citizenship behaviors, are affected by responsible leadership. From the perspective of internal employees and their views of leaders' actions, empirical studies have shown the critical role of responsible leadership in employee retention and satisfaction with the organization, as well as their socially responsible and ethical foundation $[28,29]$.

BF Daily, JW Bishop and N Govindarajulu [5] defined OCBE as voluntary acts conducted by employees toward environmental improvement within the organization. The literature shows that leadership styles are considered to have an essential effect on corporate 'greening' and employee OCBE $[10,15,30,31]$. According to this logic, we infer that employee OCBE could be specifically embedded in responsible leadership. First, as responsible leaders create a values-oriented vision of the 
future, they tend to draw a broader picture of a desirable social, human and sustainable aspect [16] which will challenge employee perspectives about their choices, like caring about the sustainable development of the organization. Second, by sending a signal to the current organization about their sustainable values and priorities, responsible leaders will set an example and heighten employee awareness of responsibility [32,33]. Third, while emphasizing discussion of CSR, responsible leaders also consider the needs and interests of their employees by caring about their personal growth and career development or fostering a cooperative and human working climate in the company. These initiatives may drive employee's feedback to the organization, such as sacrificing their own time or energy responding to sustainable policies [31]. We therefore hypothesize:

Hypothesis 1. Responsible leadership will be positively related to employee OCBE.

\subsection{The Mediating Role of Leader Identification}

According to social identity theory, identification is the process in which an individual forms a mental connection with "targets", including organization, occupation, leaders, or co-workers [34]. Among the different "targets", leader identification implies that the ways in which subordinates emulate and learn from their leaders depend on the level at which those subordinates identify with their leaders [35]. Responsible leadership is concerned with CSR or extended stakeholder management where leaders live up to their responsibilities [36,37]. NM Pless [15] defined responsible leadership as being "value-based", and went on to point out that "ethical principles have driven the relationship between leaders and stakeholders." It transforms traditional leadership from the dyadic leader-follower model to leader-stakeholder interactions [15]. As key stakeholders, employees are taken seriously by responsible leadership; responsible leaders can exert influence on employee self-concepts such as personal identification. They are committed to articulating a promising vision and to setting a model to be emulated, and they also pay much attention to their subordinates' needs. For example, responsible leaders are willing to produce humanized decisions, care about employee benefit and, if possible, seek mutually beneficial solutions [15]. These measures express leaders' concerns and attract employee sympathy, while increasing their sense of higher purpose. Consequently follower convictions about responsible leaders become self-referential and self-defining, and trust bonds with leaders are established. Scholars suggest that people identify more with leaders when trust is present, and their needs are satisfied [38,39]. Under these circumstances, responsible leadership can increase employee-leader identification.

What's more, responsible leadership is seen as a leadership style of great charm, because of characteristics such as global view, CSR consciousness, long-term perspective, etc. It is evident when an individual attempts to emulate their leaders, because these characteristics will be present. Therefore, the emulation process will help subordinates foster a mental connection with responsible leaders. Consistent with recent theoretical and empirical studies [29], we use the term 'leader identification' to indicate the extent to which leaders are included in subordinates' relational selves. That is to say, responsible leadership is likely to encourage employees to share the leader's norms and goals, and thus, to incorporate the leader as an essential partner in their own self-identity.

Social identity theory further proposes that when subordinates' are feeling greater leader identification, they tend to be more willing to act on the leader's behalf. Because they share similar interests with their leaders and treat the leader's perspectives and beliefs as their own, they become inclined to imitate and respond to the leader's values, norms, and visions to define their own job roles. For example, they are more likely to perform volunteering extra-role behaviors which go beyond their job descriptions [40], such as in the case of OCBE. They will be more considerate vis a vis the leader's requirements, and more willing to satisfy the leader's expectations. They will generate a stronger will to develop and maintain favorable social exchange relations with the identified responsible leaders. Individual leader identification promotes the influence of leaders because of employees' increased sensitivity to their leader's practices and expectations. According to this logic, we infer that when 
responsible leadership focuses on the sustainability performance of the company and sets an example for how to follow sustainable principles, subordinates who identify with that leader will also view these short- or long-term plans and demands as being useful and necessary. At the same time, they will follow the leader's example by performing OCBE to respond to initiatives such as reducing energy consumption, saving resources, making suggestions to minimize construction waste, and working in an environmental-friendly way [41]. Thus, we argue that responsible leadership and leader identification are essential constructs for OCBE. We therefore hypothesize:

Hypothesis 2. Leader identification mediates the positive relationship between responsible leadership and employee OCBE.

\subsection{The Moderating Role of PRESOR}

Empirical studies imply that the individual's sustainable behavior makes a significant contribution to corporate greening and to the implementation of environmental programs within the organization [8, 42]. However, the extra-role initiatives of employees depend in no small part on their specific characteristics and values, especially regarding OCBE, which cannot be required through formal regulation systems alone, and relies on the spontaneous and voluntary involvement of individuals. The concept of PRESOR was first developed by A Singhapakdi, SJ Vitell, KC Rallapalli, and KL Kraft [43], who believe that when employees make personal decisions, it is vital for them to first perceive ethics and social responsibility to be important; subsequently, they behave more ethically and reflect greater social responsibility [23,43]. This is in line with CSR practices and the environmental philosophy of the organization [25]. Therefore, PRESOR refers to employee recognition of the role of self-ethics and social responsibility as they relate to organizational effectiveness [44]. Empirical studies have shown that employee perceptions [45], attitudes [46], and behaviors [47] are significantly different under high- and low-PRESOR conditions. Compared to low-PRESOR individuals, high-PRESOR individuals have a greater sense of ethics and social responsibility, which urge them to consider the potential impacts upon the organization and society when making personnel decisions. Once subordinates have a strong awareness of ethics and social responsibility, their motivation to adjust their behavior and behave responsibly tend to be more influenced by their identification with responsible leaders. Employees are more prone to perceiving responsible leadership behaviors as genuine signals that the leader is devoted to long-term relationships, and developing strong social-emotional bonds beyond cost and beneficial transactions. This supervisor-subordinate relationship tends to encourage employees to share the leader's work norms and goals, and thus, to personally identify with the leader. This identification will drive employee feedback to the organization, and employees are more willing to engage in OCBE behavior, such as recycling paper, voluntary voicing behavior and sharing the knowledge and skills of environmental protection [10]. In this case, high PRESOR may enhance the relationship between leader identification and OCBE and also the positive impact of responsible leadership on the OCBE via leader identification.

In contrast, an individual with low PRESOR tends to perceive that his/her own benefit outweighs the importance of CSR or ethics and social responsibility values, and he/she is likely to oppose such behavior. Motivation to perform OCBE are more likely to be affected by the compulsory regulations and rewards of the organization; as such, it is difficult for them to accept and respond to a responsible leader's values and to identify with the leader [44]. Under these circumstances, leaders have to work harder to establish a relationship, so that employees can become aware of their responsibility to conduct ethical behavior that is needed, but not rewarded, by the organization's practices [45]. C Pettijohn, L Pettijohn and AJ Taylor [46] found that higher PRESOR scores are associated with better cognition and responsible behavior. Therefore we put forward the following model: 
Hypothesis 3. The individual's PRESOR moderates the positive relationship between leader identification and employee OCBE. It also moderates the mediated relationship between responsible leadership and employee OCBE. The mediated relationship is stronger at a high level of an individual's PRESOR than at a low level.

\section{Materials and Methods}

\subsection{Sample and Procedure}

To reduce common method variance and illusionary correlations, we adopted a longitudinal research design with two stages; the time lag was five months. Matching codes were employee identification numbers, which were known to the employees only. Specifically, employees completed their questionnaires separately and reported their identification numbers, which made it convenient to identify them in the second stage. The questionnaires were separately completed during working hours and were collected by the researchers in different stages. With the assistance of a service chain hotel in Shanghai, China, we conducted a two-phase survey between 2017 and 2018. Participants were employees whose information was provided by the human resource department. In December 2017 (time point 1), we distributed the first batch of questionnaires on responsible leadership, leader identification and PRESOR to 400 employees, among which 340 were returned (after excluding 60 invalid samples), registering an effective rate of 85\%. In May 2018 (time point 2), according to participants' identification numbers, we distributed the second batch of questionnaires on OCBE according to same procedure. Finally, 302 valid questionnaires were collected, resulting in an overall response rate of $88.8 \%$. Among our sample of 302 subordinates, $156(51.7 \%)$ were male; the average age was 23.75 years $(\mathrm{SD}=4.25)$, and the average organizational tenure was 1.56 years $(\mathrm{SD}=3.07)$.

\subsection{Measurement of Variables}

To ensure the scientific soundness of the study, the measures we chose were initially written in English and were mature scales with high reliability and validity. Before we conducted the survey, the English language measures were translated into Chinese following translation-back-translation procedure recommendations. All measures anchored on a 5-point Likert scale ( 1 = strongly disagree; 5 = strongly agree).

Responsible leadership. We assessed responsible leadership using the 5-item responsible leadership scale developed by C Voegtlin [28]. Sample items included "My direct supervisor demonstrates awareness of the relevant stakeholder claims" and "My direct supervisor considers the consequences of decisions for the affected stakeholders." The scale's coefficient alpha in this study was 0.89 .

Leader identification. We measured leader identification using five items from $F$ Mael and BE Ashforth's [48] and B Shamir, E Zakay, E Breinin and M Popper's [49] leader identification scale. The sample items were: "When someone praises my leader, it feels like a personal compliment", and "My leader's successes are my success." The scale's coefficient alpha was 0.88 .

Ten items were used to measure OCBE [6]. Sample items were: "I encourage my colleagues to express their ideas and opinions on environmental issues" and "I spontaneously speak to my colleagues to help them better understand environmental problems." Scale reliability was determing to be 0.95. Following P Paillé, Y Chen, O Boiral and J Jin [50], we used the one-factor model of OCBE. To test the homogeneity of OCBE's three sub-dimensions, we conducted a second-order confirmatory factor analysis (CFA). Among the ten measurements, three were loaded into the sub-dimensions of eco-initiatives, while the other four and three were loaded into eco-civic engagement, and eco-helping respectively. All three sub-dimensions were loaded into a second-order factor to test OCBE. Using MPLUS 7.0, we examined the model fit of Chi-square $\left(X^{2}\right), R M S E A, S R M R, C F I$, and TLI. The second-order CFA results showed a good fit for the data $\left(X^{2}=44.64, R M S E A=0.07\right.$, $S R M R=0.03, C F I=0.97, T L I=0.96)$. The full scale's coefficient alpha was 0.97 , which exhibited a high level of reliability. 
We adopted the five-item scale developed from JM Etheredge [51] to measure PRESOR. It should be noted that PRESOR measurement consisted of two factors (PRESOR importance and subordination). Given that this article focuses on the perceived importance of ethics and social responsibility in achieving organizational effectiveness, we used PRESOR importance to measure PRESOR, for example: "Being ethical and socially responsible is the most important thing a firm can do" and "Business has a social responsibility beyond making a profit." The scale's coefficient alpha was 0.94 .

Control variables. We chose several variables as controls, such as gender, age, career tenure, and organizational ethical climate, mainly because these variables are likely to have an impact on employee OCBE $[52,53]$. Specifically, gender was coded as $0=$ male and $1=$ female; age and organizational tenure were set according to the actual situation of the participants. Additionally, the nature of the organization's ethical climate was also controlled in this study, because the literature suggests that the organizational ethical climate plays an instrumental role in organization member's ethical decision making, and that this can foster ethical values such as honesty and trust. If the organizational climate is pro-environmental, employees are more likely to perform OCBE [54]. The organizational ethical climate scale came from a 7-item developed by CH Schwepker [55].

\section{Results}

\subsection{Confirmatory Factor Analysis (CFA)}

As our data were collected from the same source, with maximum likelihood estimation using MPLUS7.0, we conducted confirmatory factor analyses to examine the construct distinctiveness of our four main measures. The CFA results in Table 1 show that the hypothesized four-factor model provided the best fit to the data $\left(X^{2}=287.17, d f=146, R M S E A=0.06, S R M R=0.05, C F I=0.95, T L I=0.95\right)$, compared with the other four alternative models. For example, three-factor model 1 was responsible leadership and PRESOR combined into one factor $\left(X^{2}=871.69, d f=149, R E S E A=0.13, S R M R=0.12\right.$, $C F I=0.77, T L I=0.73)$; three-factor model 2 was responsible leadership and leader identification combined into a single factor $\left(X^{2}=430.05, d f=149, R M S E A=0.08, S R M R=0.06, C F I=0.91, T L I=0.90\right)$, which fit the data significantly less well. These results proved that the four-factor model was the most appropriate, and provided support for the discriminant validity of our variables.

Table 1. Results of confirmatory factor analysis of the measurement models.

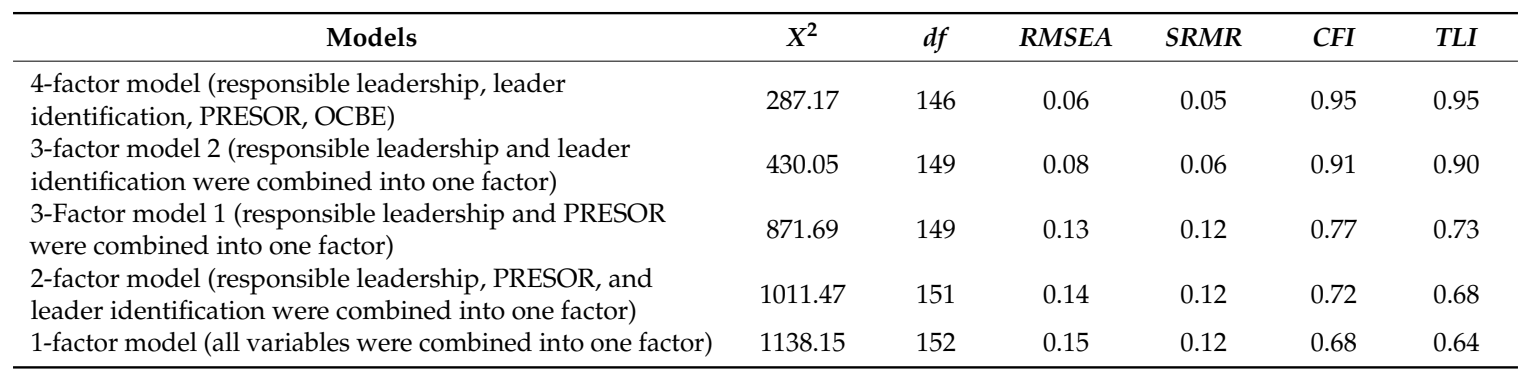

Note: $N=302$; PRESOR represents the Perceived Role of Ethics and Social Responsibility; OCBE represents Organizational Citizenship Behavior for the Environment; RMSEA is the Root-Mean-Square Error of Approximation; SRMR is the Standardized Root Mean Square Residual; TLI is the Tucker-Lewis Index; CFI is the Comparative Fit Index; ${ }^{*} p<0.05 ;{ }^{* *} p<0.01$.

\subsection{Descriptive Statistics}

Table 2 shows the main variables of means, standard deviations and correlations. In addition, responsible leadership was strongly related to leader identification $(\mathrm{r}=0.60, p<0.01)$ and OCBE $(\mathrm{r}=0.74, p<0.01)$; leader identification and OCBE $(\mathrm{r}=0.64, p<0.01)$ also had a positively correlation. 
Table 2. Means, standard deviations and correlations for the study variables.

\begin{tabular}{|c|c|c|c|c|c|c|c|c|c|c|}
\hline Variable & Mean & SD & 1 & 2 & 3 & 4 & 5 & 6 & 7 & 8 \\
\hline 1. Gender & 1.49 & 0.50 & - & & & & & & & \\
\hline 2. Age & 23.75 & 4.27 & -0.08 & - & & & & & & \\
\hline 3. Tenure & 1.56 & 3.07 & $-0.11 *$ & $0.71 * *$ & - & & & & & \\
\hline 4. Organizational ethical climate & 3.71 & 0.80 & -0.10 & 0.04 & -0.05 & - & & & & \\
\hline 5. Responsible leadership & 3.71 & 0.83 & -0.07 & -0.05 & $-0.18^{* *}$ & $0.63^{* *}$ & - & & & \\
\hline 6. Leader identification & 3.97 & 0.75 & -0.04 & -0.03 & -0.10 & $0.66^{* *}$ & $0.60 * *$ & - & & \\
\hline 7.OCBE & 3.82 & 0.76 & -0.08 & 0.00 & $-0.14^{*}$ & $0.68^{* *}$ & $0.74 * *$ & $0.64^{* *}$ & - & \\
\hline
\end{tabular}

Note: $N=302$; OCBE represents Organizational Citizenship Behavior for the Environment; PRESOR represents the Perceived Role of Ethics and Social Responsibility; ${ }^{*} p<0.05 ;{ }^{* *} p<0.01$.

\subsection{Hypothesis Testing}

\subsubsection{Direct Effect Hypothesis}

H1 suggested that responsible leadership would be positively related to employee OCBE. The SEM analysis from Figure 2 shows that the model fit to the data well; $X^{2}(101)=195.04, X^{2} / d f=1.93$ $(R M S E A=0.06, S R M R=0.05, C F I=0.96, T L I=0.95)$ and the path from responsible leadership to employee's OCBE $(\beta=0.58, p<0.01)$ was positive and significant. Thus, our H1 was supported. Additionally, Figure 2 also demonstrates some evidence of a mediating effect; however, whether it was the full or partial mediation suggested in $\mathrm{H} 2$ remains to be determined.

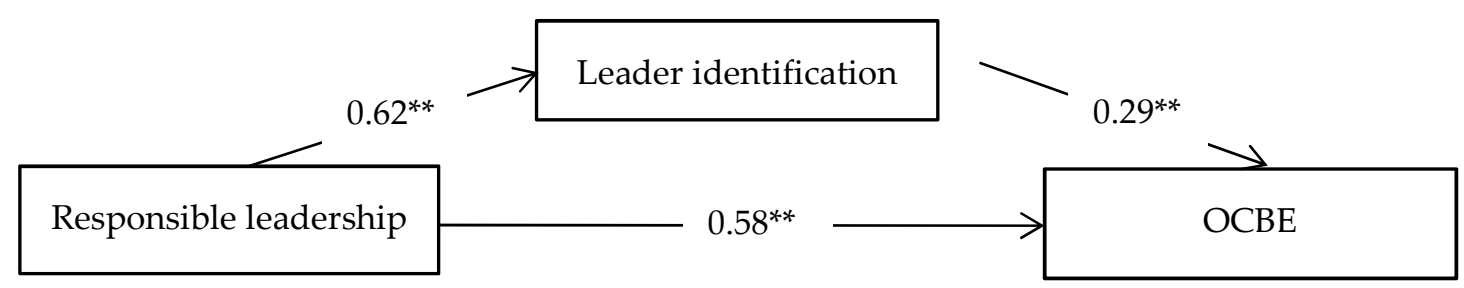

Figure 2. Structural equation modeling results. Note: The effect of control variables are not shown; Values represent standardized estimates; OCBE represents Organizational Citizenship Behavior for the Environment; ${ }^{*} p<0.05 ;{ }^{* *} p<0.01$.

\subsubsection{Mediation Analyses}

Following the suggestions of KJ Preacher, DD Rucker and AF Hayes [56], we compared our proposed model to an alternative model, with no direct path from responsible leadership to employee OCBE, in other words, via a fully mediated model. The fit indices and path estimates showed that the alternative model fit poorly with the data. $X^{2}(102)=242.66, X^{2} / d f=1.93(R M S E A=0.07, S R M R$ $=0.09, C F I=0.94, T L I=0.93$ ). Therefore, we chose the proposed model as the final model, and the hypothesis that leader identification partially mediates the relationship between responsible leadership and employee OCBE was supported by our data.

We employed bootstrap to test the SEM results, that is, we examined the indirect effect responsible leadership on OCBE through leader identification by estimating and constructing a $95 \%$ bias-corrected confidence interval. The impact is significant if the confidence interval does not overlap zero. The results in Table 3 (estimate $=0.26$ ) demonstrate that responsible leadership has a significant indirect effect on employee OCBE, with the confidence interval (CI) ranging from 0.14 to 0.41 . Thus, our $\mathrm{H} 2$ was supported. 
Table 3. Results of complete standardization of the main path coefficients of the leader-identification mediating model.

\begin{tabular}{cccccc}
\hline Effects & Estimate & S.E. & Est./S.E. & P-Value & $\begin{array}{c}\text { 95\% Confidence } \\
\text { Interval }\end{array}$ \\
\hline $\begin{array}{c}\text { Responsible leadership } \rightarrow \text { OCBE } \\
\text { Responsible leadership } \rightarrow \text { Leader identification }\end{array}$ & $0.33^{* *}$ & 0.11 & 3.00 & 0.00 & {$[0.13,0.56]$} \\
$\begin{array}{c}\text { Leader identification } \rightarrow \text { OCBE } \\
\text { Responsible leadership } \rightarrow \text { Leader identification } \\
\quad \rightarrow \text { OCBE }\end{array}$ & $0.35^{* *}$ & 0.08 & 9.19 & 0.00 & {$[0.59,0.90]$} \\
$\quad 0.26^{* *}$ & 0.07 & 3.84 & 0.00 & {$[0.17,0.54]$} \\
\hline
\end{tabular}

Note: OCBE represents Organizational Citizenship Behavior for the Environment; ${ }^{*} p<0.05$; ${ }^{* *} p<0.01$.

\subsubsection{Moderation Analyses}

H3 suggested that an individual's PRESOR will moderate the positive relationship between leader identification and employee OCBE. As shown in Table 4, the interactive effect of leader identification and PRESOR was significant $(\beta=0.68, p<0.05)$. The moderation effect received support, which implied that the individual's PRESOR did have a moderating effect between leader identification and employee OCBE.

Table 4. The moderating effect of PRESOR between leader identification and employee OCBE.

\begin{tabular}{cccc}
\hline Variables & \multicolumn{3}{c}{ OCBE } \\
\cline { 2 - 4 } & M1 & M2 & M3 \\
\hline Control variables & & & \\
Gender & -0.04 & -0.04 & -0.03 \\
Age & $0.11^{*}$ & $0.11^{*}$ & $0.11^{*}$ \\
Tenure & $-0.18^{* *}$ & $-0.18^{* *}$ & $-0.18^{* *}$ \\
Organizational Ethical Climate & $0.45^{* *}$ & $0.45^{* *}$ & $0.44^{* *}$ \\
Independent variable & & & \\
Leader identification & $0.32^{* *}$ & $0.32^{* *}$ & 0.12 \\
Moderated variable & & & \\
PRESOR & & -0.01 & $-0.65^{*}$ \\
Interaction & & & $0.68^{*}$ \\
$R^{2}$ & & 0.54 & 0.55 \\
$\Delta R^{2}$ & 0.54 & 0.00 & 0.01 \\
$F$ & 0.54 & $57.88^{* *}$ & $51.47^{* *}$ \\
$\Delta F$ & $69.68^{* *}$ & 0.02 & $6.52^{*}$
\end{tabular}

Note: $N=302 ;$ PRESOR represents the Perceived Role of Ethics and Social Responsibility; ${ }^{*} p<0.05 ;{ }^{* *} p<0.01$.

The analysis of the moderated mediation effect in Table 5 demonstrated that responsible leadership had a more positively indirect impact on employee OCBE when the individual's level of PRESOR was high (estimate $=0.03$, bias-corrected CI [0.03, 0.16]), while with a low level of PRESOR, the indirect effect of responsible leadership was not significant for employee OCBE (estimate $=0.03$, bias-corrected CI $[-0.02,0.09])$. The index of moderated mediation was significant (estimate $=0.01$, bias-corrected CI $[0.01,0.05])$. Taken together, an individual's PRESOR moderates the mediated relationship between responsible leadership and employee OCBE. Therefore, we have evidence to support H3. 
Table 5. Results for the conditional indirect effect of responsible leadership on employee's OCBE via leader identification across levels of PRESOR.

\begin{tabular}{|c|c|c|c|c|c|c|c|c|}
\hline $\begin{array}{l}\text { Dependent } \\
\text { Variable }\end{array}$ & Mediator & Moderator & Level & Mean & $\begin{array}{l}\text { Effect } \\
\text { Size }\end{array}$ & Boot SE & $\begin{array}{l}\text { LL } 95 \% \\
\text { CI }\end{array}$ & $\begin{array}{l}\text { UL } 95 \% \\
\text { CI }\end{array}$ \\
\hline \multirow{3}{*}{ OCBE } & \multirow{3}{*}{$\begin{array}{c}\text { Leader } \\
\text { identification }\end{array}$} & \multirow{2}{*}{ PRESOR } & Low $(-1 \mathrm{SD})$ & 1.14 & 0.02 & 0.03 & -0.02 & 0.09 \\
\hline & & & High (+1 SD) & 3.74 & 0.08 & 0.03 & 0.03 & 0.16 \\
\hline & & PRESOR & & & 0.02 & 0.01 & 0.01 & 0.05 \\
\hline
\end{tabular}

Note: $N=302$; OCBE represents Organizational Citizenship Behavior for the Environment; PRESOR represents the Perceived Role of Ethics and Social Responsibility.

\section{Discussion}

In this study, based on social identity theory, we discussed the reasons why responsible leadership influences employee OCBE, and how employee characteristics influenced the effect of responsible leadership, from a two-phase survey data collection in the hospitality industry. We found that: (a) responsible leadership was positively related to employee OCBE; (b) leader identification partially mediated the relationship between responsible leadership and OCBE; (c) PRESOR moderated the positive influence of leader identification on employee OCBE; and (d) with a high level of individual PRESOR, the indirect effect of responsible leadership on OCBE through leader identification was more significant. In other words, those who realized the importance of ethics and responsibility tended to be more positive in response to the propositions of responsible leaders than those who thought that their personal benefit outweighed the importance of ethical and socially responsible values. These conclusions extend our explanation of the influence mechanism and conditions through which responsible leadership affects employee extra-role behavior.

\subsection{Theoretical Implications}

The findings in this study have three theoretical implications. First, this paper contributes to the antecedents of OCBE and explains the formation mechanism. We found that responsible leadership was positively related to OCBE; this was in line with the findings of previous studies [57,58], which argued that responsible leadership was essential to promoting sustainability-related behavior (e.g., OCBE) among employees, because responsible leaders can send signals to current employees about their sustainable values and priorities, and as a consequence, employees tend to emulate and perform OCBE. Compared to traditional leadership from the dyadic leader-follower perspective, responsible leadership contributes to the improvement of personal sustainable behavior, regarding employees as key stakeholders. Therefore, organizations with responsible leaders should generate superior sustainability practices due to their emphasis on aligning a responsible leader's perspectives or beliefs with the internal personal environment efforts. As such, we extend the OCBE literature by identifying responsible leadership as a new predictor of OCBE. This study is among the first to explore the influence of leadership style on OCBE and to provide empirical evidence about the positive effect of responsible leadership on employee OCBE.

Second, in addition to exploring a direct relationship between responsible leadership and OCBE, this study also found that employee identification with the leaders of the organization partially mediated the relationship mentioned above. Our results contribute to the empirical research evidence for the impact of responsible leadership on the OCBE formation mechanism. Actually, research on OCBE is in an early stage, and prior research of the influence path is limited by the traditional research paradigm which primarily focused on the direct effect of supervisors (e.g., leader support) on OCBE, but ignored employees' inner self-concepts [6]. Social identity theory helps to explain the complex mechanisms of responsible leadership as they relate to OCBE; responsible leaders can exert influence on the employees' self-concepts, such as personal identification, which influences employee values and increases their sense of a higher purpose. When employees identify with their leaders, they are more likely to accept those leaders' norms and values and act on the leader's behalf [59]. What's 
more, this study also underscores the importance of leader identification compared to other targets of identification (e.g., organization identification), which was found to connect with the concepts of employee behavior that have been proved previously in organizational research. TA Jenkin, L McShane and J Webster [60] proposed that organizational sustainable orientation would affect OCBE. In such cases, responsible leadership and leader identification can be good explaining mechanisms. Therefore, future studies should examine more outcomes of leader identification to determine whether these conclusions are similar to those of organizational identification.

Third, we contribute a new boundary condition, PRESOR, as a moderating role, under which leadership identification affects employee OCBE, and responsible leadership indirectly affects employee OCBE via leader identification. Therefore, employees with high levels of PRESOR have a keen awareness of ethics and social responsibility, and are motivated to adjust their behavior to bring it in line with that of their leaders. From the perspective of individual traits, PRESOR reveals the "black box" of the mechanism and extends the literature on responsible leadership, in that we demonstrate a necessary boundary condition for how and when responsible leaders affect employee behavior. Furthermore, by clearly figuring out the moderated role of PRESOR, we respond to the call of E Lamm, J Tosti-Kharas and EG Williams [30] for more research on personal characteristics to understand followers' OCBE. We also echo D Dawson's [45] and C Pettijohn, L Pettijohn, and AJ Taylor's [46] research, which implied that employee attitudes and behavior are significantly affected by different PRESOR conditions.

\subsection{Practical Implications}

Some scholars have started to recognize that stimulating the enthusiasm of employees is one of the most effective methods for organizations to maximize economic performance [61,62]. From a practical perspective, our study has two implications. First, with the current situation of increasingly strain on the environment, some organizations must expect more from their employees in terms of performing extra-role or proactive tasks, such as OCBE. Our findings indicate that the organization should consider responsible leadership to motivate employees. Responsible leaders can send signals to the current organization about their sustainable values and priorities to heighten their subordinates' levels of awareness of responsibility.

Additionally, from the findings on the mediation effect, we can infer that an effective way to motivate employee OCBE is to increase leader identification. Leaders can provide individualized support, such as considering their followers' needs, listening to their new ideas, and encouraging personal growth. As a result, a trusting, responsible and supportive climate is developed, and employees may feel valuable and safe to engage in OCBE. Thus, our study indicates that organizational interventions focused on creating a supportive atmosphere and fostering follower identification with leaders will significantly strengthen the effectiveness of responsible leadership.

Second, our findings suggest that personal characteristics are also fundamental (e.g., PRESOR) to the relationship between responsible leadership, leader identification, and OCBE; therefore, leaders need to pay attention to individuals with high PRESOR, who are ethics- and social responsibility-oriented. If leaders encourage and praise them, an excellent organizational atmosphere can be created in which those employees serve as exemplary models. In a word, when trying to motivate productive behavior among employees in an organization, it is essential to comprehensively consider factors of the personal traits of each employee, leadership style and the organizational system.

\subsection{Limitations and Future Directions}

There are some limitations and many avenues for future research that need to be acknowledged. First, because all of our variables come from the same source, there might be problems of common method biases. Although we conducted a two-phase survey and used confirmatory factor analysis for our model comparison and discriminant tests, future research should still pay attention to the 
influence of common method biases. We call for a more extended period and longitudinal analysis to determine causality in the future.

Second, we overlooked other mediated and moderated paths affecting OCBE, since, in this research, we only focus on one mediated (leader identification) and moderated factor (PRESOR). In the future, additional research should attempt to determine the mechanisms of responsible leadership on OCBE, such as coworker exchange and leader support as mediated variables, and environmental climate and employee goal orientation as the moderated factors which may affect the relationship between responsible leadership and OCBE. What's more, researchers can also consider other antecedents of OCBE. E Lamm, J Tosti-Kharas and EG Williams [30] indicated that OCBE is the result of multiple interactions of individuals, team, and even firm-level factors. For example, because of the rapid development of work teams, antecedents at the team level may have stronger effects, in terms of team climate or cohesion.

Third, our data came from only one kind business organizations in China. E Temminck, K Mearns and L Fruhen [7] have indicated that the particularities of a given type of enterprise would cause data deviation when analyzing OCBE. So, considering the context-dependence of OCBE, data from different aspects in future research are necessary, which can guarantee the generalization of the results to some extent.

\section{Conclusions}

In this study, we found that responsible leadership is a vital antecedent for OCBE, which has a positive effect on promoting employee OCBE through leader identification. Employee PRESOR is an essential variable in moderating the relationship between leader identification and employee OCBE, which also moderates the indirect positive effect of responsible leadership on OCBE through leader identification. Thus, our study provides evidence of the effective mechanisms of responsible leadership on OCBE, which contributes to the theoretical and practical implications of our findings.

Author Contributions: Conceptualized, reviewed, funding acquisition, and supervised this study, H.Z.; Conceptualized, drafted methodology, data collected \& analyzed, and wrote original draft, Q.Z.

Funding: This research was funded by National Natural Science Foundation of China (Grant No. 71772116).

Acknowledgments: The authors would like to acknowledge the financial support provided by National Natural Science Foundation of China (Grant No. 71772116).

Conflicts of Interest: The authors declare no conflict of interest.

\section{References}

1. Manaktola, K.; Jauhari, V. Exploring consumer attitude and behavior towards green practices in the lodging industry in India. Int. J. Contemp. Hosp. M. 2007, 19, 364-377. [CrossRef]

2. Bohdanowicz, P. European hoteliers' environmental attitudes: Greening the business. Cornell. Hotel. Rest. A. 2005, 46, 188-204. [CrossRef]

3. Kim, Y.J.; Kim, W.G.; Choi, H.M.; Phetvaroon, K. The effect of green human resource management on hotel employees' eco-friendly behavior and environmental performance. Int. J. Hosp. Manag. 2019, 76, 83-93. [CrossRef]

4. Harris, L.C.; Crane, A. The greening of organizational culture: Management views on the depth, degree and diffusion of change. J. Organ. Change. Manag. 2002, 15, 214-234. [CrossRef]

5. Daily, B.F.; Bishop, J.W.; Govindarajulu, N.A. Conceptual model for organizational citizenship behavior directed toward the environment. Bus. Soc. 2009, 48, 243-256. [CrossRef]

6. Boiral, O.; Paillé, P. Organizational citizenship behavior for the environment: Measurement and validation. J. Bus. Ethics. 2012, 109, 431-445. [CrossRef]

7. Temminck, E.; Mearns, K.; Fruhen, L. Motivating employees towards sustainable behaviour. Bus. Strateg. Environ. 2015, 24, 402-412. [CrossRef]

8. Roy, M.J.; Boiral, O.; Paillé, P. Pursuing quality and environmental performance: Initiatives and supporting processes. Bus. Process. Manag. J. 2013, 19, 30-53. [CrossRef] 
9. Smith, A.M.; O'Sullivan, T. Environmentally responsible behaviour in the workplace: An internal social marketing approach. J. Market. Manag. 2012, 28, 469-493. [CrossRef]

10. Egri, C.P.; Herman, S. Leadership in the North American environmental sector: Values, leadership styles, and contexts of environmental leaders and their organizations. Acad. Manage. J. 2000, 43, 571-604.

11. Ramus, C.A. Organizational support for employees: Encouraging creative ideas for environmental sustainability. Calif. Manage. Rev. 2001, 43, 85-105. [CrossRef]

12. Ramus, C.A.; Steger, U. The roles of supervisory support behaviors and environmental policy in employee “Ecoinitiatives" at leading-edge European companies. Acad. Manage. J. 2000, 43, 605-626.

13. Maak, T. Responsible leadership, stakeholder engagement, and the emergence of social capital. J. Bus. Ethics. 2007, 74, 329-343. [CrossRef]

14. Maak, T.; Pless, N.M. Responsible leadership in a stakeholder society-A relational perspective. J. Bus. Ethics. 2006, 66, 99-115. [CrossRef]

15. Pless, N.M. Understanding responsible leadership: Role identity and motivational drivers. J. Bus. Ethics. 2007, 74, 437-456. [CrossRef]

16. Kets de Vries, M.F.; Vrignaud, P.; Florent-Treacy, E. The global leadership life inventory: Development and psychometric properties of a 360-degree feedback instrument. Int. J. Hum. Resour. Man. 2004, 15, 475-492. [CrossRef]

17. Podsakoff, P.M.; MacKenzie, S.B.; Moorman, R.H.; Fetter, R. Transformational leader behaviors and their effects on followers' trust in leader, satisfaction, and organizational citizenship behaviors. Leadership. Quart. 1990, 1, 107-142. [CrossRef]

18. Wang, H.; Law, K.S.; Hackett, R.D.; Wang, D.; Chen, Z.X. Leader-member exchange as a mediator of the relationship between transformational leadership and followers' performance and organizational citizenship behavior. Acad. Manage. J. 2005, 48, 420-432. [CrossRef]

19. Shamir, B.; House, R.J.; Arthur, M.B. The motivational effects of charismatic leadership: A self-concept based theory. Organ. Sci. 1993, 4, 577-594. [CrossRef]

20. Gong, Y.; Huang, J.C.; Farh, J.L. Employee learning orientation, transformational leadership, and employee creativity: The mediating role of employee creative self-efficacy. Acad. Manage. J. 2009, 52, 765-778. [CrossRef]

21. Carmeli, A.; Gilat, G.; Waldman, D.A. The role of perceived organizational performance in organizational identification, adjustment and job performance. J. Manage. Stud. 2007, 44, 972-992. [CrossRef]

22. Walumbwa, F.O.; Hartnell, C.A. Understanding transformational leadership_Employee performance links: The role of relational identification and self-efficacy. J. Occup. Organ. Psych. 2011, 84, 153-172. [CrossRef]

23. Hunt, S.D.; Vitell, S. A general theory of marketing ethics. J. Macromarketing. 1986, 6, 5-16. [CrossRef]

24. Vitell, S.J.; Paolillo, J.G. A cross-cultural study of the antecedents of the perceived role of ethics and social responsibility. Bus. Ethics. 2004, 13, 185-199. [CrossRef]

25. Singhapakdi, A.; Karande, K.; Rao, C.P.; Vitell, S.J. How important are ethics and social responsibility?-A multinational study of marketing professionals. Eur. J. Marketing. 2001, 35, 133-153. [CrossRef]

26. Pless, N.M.; Maak, T. Responsible leadership: Pathways to the future. J. Bus. Ethics. 2011, 98, 3-13. [CrossRef]

27. Groves, K. Integrating leadership development and succession planning best practices. Eng. Manag. Rev. 2011, 39, 64-81. [CrossRef]

28. Voegtlin, C. Development of a scale measuring discursive responsible leadership. J. Bus. Ethics. 2011, 98, 57-73. [CrossRef]

29. Lord, R.G.; Brown, D.J. Leadership, values, and subordinate self-concepts. Leadership. Quart. 2001, 12, 133-152. [CrossRef]

30. Lamm, E.; Tosti-Kharas, J.; Williams, E.G. Read this article, but don't print it: Organizational citizenship behavior toward the environment. Group. Organ. Manage. 2013, 38, 163-197. [CrossRef]

31. Boiral, O.; Baron, C.; Gunnlaugson, O. Environmental leadership and consciousness development: A case study among Canadian SMEs. J. Bus. Ethics. 2011, 123, 363-383. [CrossRef]

32. Bowler, W.M.; Halbesleben, J.R.; Paul, J.R. If you are close with the leader, you must be a brownnose: The role of leader-member relationships in follower, leader, and coworker attributions of organizational citizenship behavior motives. Hum. Resour. Manage. R. 2010, 20, 309-316. [CrossRef]

33. Yaffe, T.; Kark, R. Leading by example: The case of leader OCB. J. Appl. Psychol. 2011, 96, 806-826. [CrossRef] [PubMed] 
34. Scott, C.R.; Corman, S.R.; Cheney, G. Development of a structurational model of identification in the organization. Commun. Theor. 1998, 8, 298-336. [CrossRef]

35. Li, Y.; Sun, J.M. Traditional Chinese leadership and employee voice behavior: A cross-level examination. Leadership. Quart. 2015, 26, 172-189. [CrossRef]

36. Palazzo, G.; Scherer, A.G. Corporate social responsibility, democracy, and the politicization of the corporation. Acad. Manage. Rev. 2008, 33, 773-775. [CrossRef]

37. Waldman, D.A.; Galvin, B.M. Alternative perspectives of responsible leadership. Organ. Dyn. 2008, 37, 327-341. [CrossRef]

38. De Cremer, D.; Van Knippenberg, D. How do leaders promote cooperation? The effects of charisma and procedural fairness. J. Appl. Psychol. 2002, 87, 858-866. [CrossRef]

39. Van Knippenberg, D.; Van Knippenberg, B.; De Cremer, D.; Hogg, M.A. Leadership, self, and identity: A review and research agenda. Leadership. Quart. 2004, 15, 825-856. [CrossRef]

40. Sluss, D.M.; Ashforth, B.E. How relational and organizational identification converge: Processes and conditions. Organ. Sci. 2008, 19, 807-823. [CrossRef]

41. Maier, E.R.; Branzei, O. "On time and on budget": Harnessing creativity in large scale projects. Int. J. Proj. Manag. 2014, 32, 1123-1133. [CrossRef]

42. Boiral, O.; Talbot, D.; Paillé, P. Leading by example: A model of organizational citizenship behavior for the environment. Bus. Strat. Env. 2015, 24, 532-550. [CrossRef]

43. Singhapakdi, A.; Vitell, S.J.; Rallapalli, K.C.; Kraft, K.L. The perceived role of ethics and social responsibility: A scale development. J. Bus. Ethics. 1996, 15, 1131-1140. [CrossRef]

44. Singhapakdi, A.; Gopinath, M.; Marta, J.K.; Carter, L.L. Antecedents and consequences of perceived importance of ethics in marketing situations: A study of Thai businesspeople. J. Bus. Ethics. 2008, 81, 887-904. [CrossRef]

45. Dawson, D. Organisational virtue, moral attentiveness, and the perceived role of ethics and social responsibility in business: The case of UK HR practitioners. J. Bus. Ethics. 2008, 148, 765-781. [CrossRef]

46. Pettijohn, C.; Pettijohn, L.; Taylor, A.J. Salesperson perceptions of ethical behaviors: Their influence on job satisfaction and turnover intentions. J. Bus. Ethics. 2008, 78, 547-557. [CrossRef]

47. Park, $\mathrm{H}$. The role of idealism and relativism as dispositional characteristics in the socially responsible decision-making process. J. Bus. Ethics. 2005, 56, 81-98. [CrossRef]

48. Mael, F.; Ashforth, B.E. Alumni and their alma mater: A partial test of the reformulated model of organizational identification. J. Organ. Behav. 1992, 13, 103-123. [CrossRef]

49. Shamir, B.; Zakay, E.; Breinin, E.; Popper, M. Correlates of charismatic leader behavior in military units: Subordinates' attitudes, unit characteristics, and superiors' appraisals of leader performance. Acad. Manage. J. 1998, 41, 387-409.

50. Paillé, P.; Chen, Y.; Boiral, O.; Jin, J. The impact of human resource management on environmental performance: An employee-level study. J. Bus. Ethics. 2014, 121, 451-466. [CrossRef]

51. Etheredge, J.M. The perceived role of ethics and social responsibility: An alternative scale structure. J. Bus. Ethics. 1999, 18, 51-64. [CrossRef]

52. Graves, L.M.; Sarkis, J.; Zhu, Q. How transformational leadership and employee motivation combine to predict employee pro-environmental behaviors in China. J. Environ. Psychol. 2013, 35, 81-91. [CrossRef]

53. Newman, A.; Miao, Q.; Hofman, P.S.; Zhu, C.J. The impact of socially responsible human resource management on employee's organizational citizenship behavior: The mediating role of organizational identification. Int. J. Hum. Resour. Man. 2016, 27, 440-455. [CrossRef]

54. Zientara, P.; Zamojska, A. Green organizational climates and employee pro-environmental behaviour in the hotel industry. J. Sustain. Tour. 2018, 26, 1142-1159. [CrossRef]

55. Schwepker, C.H., Jr. Ethical climate's relationship to job satisfaction, organizational commitment, and turnover intention in the salesforce. J. Bus. Res. 2001, 54, 39-52. [CrossRef]

56. Preacher, K.J.; Rucker, D.D.; Hayes, A.F. Addressing moderated mediation hypotheses: Theory, methods, and prescriptions. Multivar. Behav. Res. 2007, 42, 185-227. [CrossRef] [PubMed]

57. Paillé, P.; Mejía-Morelos, J.H. Antecedents of pro-environmental behaviours at work: The moderating influence of psychological contract breach. J. Environ. Psychol. 2014, 38, 124-131. [CrossRef] 
58. Paillé, P.; Boiral, O.; Chen, Y. Linking environmental management practices and organizational citizenship behaviour for the environment: A social exchange perspective. Int. J. Hum. Resour. Man. 2013, 24, 3552-3575. [CrossRef]

59. Erdogan, B.; Bauer, T.N.; Taylor, S. Management commitment to the ecological environment and employees: Implications for employee attitudes and citizenship behaviors. Hum. Relat. 2015, 68, 1669-1691. [CrossRef]

60. Jenkin, T.A.; McShane, L.; Webster, J. Green information technologies and systems: Employees' perceptions of organizational practices. Bus. Soc. 2011, 50, 266-314. [CrossRef]

61. Cable, D.M.; DeRue, D.S. The convergent and discriminant validity of subjective fit perceptions. J. Appl. Psychol. 2002, 87, 875-884. [CrossRef] [PubMed]

62. Lo, S.H.; Peters, G.J.Y.; Kok, G. A review of determinants of and interventions for proenvironmental behaviors in organizations. J. Appl. Soc. Psychol. 2012, 42, 2933-2967. [CrossRef]

(C) 2019 by the authors. Licensee MDPI, Basel, Switzerland. This article is an open access article distributed under the terms and conditions of the Creative Commons Attribution (CC BY) license (http://creativecommons.org/licenses/by/4.0/). 